P85婹床病理からみた副病果件存肝細胞癌手術例における多 中心性およひ枟移性発生例の検领

大阪市立大学第 2 外科，第 2 病理・，病院病理部”・

首藤太一, 広畨一裕, 久保正二, 田中宏, 琛本忠司, 半羽宏之,

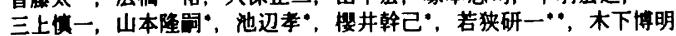

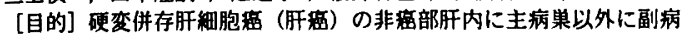

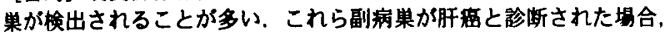
多中心性 (MC) ，枟性（IM）およひ耐者の併存する混在性 (MIX)

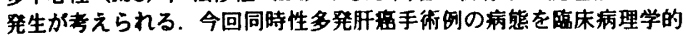
に検封した。

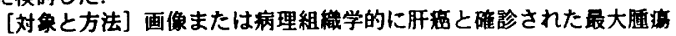
经の病巢を主病果, それ以外の全ての病果を副病果とした. 1989年 から95年末までに当科で切除した訮癌266例中，術前術中の画像跈断 または術後の切除桡本のいずれかで副病巣が㛟出され，これらを病理 組織学的に祅断しえた117峢を対象とした. 副病果は良性結節，境界

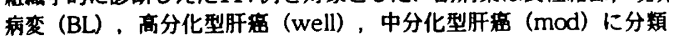
され，副病果がwellの埸合をMC, modをIMとした．また副病巣多発 刨てはwell+BLはMC, BL+modまたはwell $+\bmod の$ 埸合はMIXとし てそれぞれの頻度を算出した．さらに最大の副病果をもって副病果径 とした.

[結果] 併存副病果数は1結節55例，2結節22例で，3結節以上は40 㫜であった．副病巣の存在晾断時期は術前18例（15\%)，術中1例 (35\%)，術後58例 (50\%) であり，それぞれの平均径は1.6cm, $1.2 \mathrm{~cm}, 0.9 \mathrm{~cm}$ であた（ $\mathrm{p}<0.01 ）$. なおfalse positiveはそれぞれ1 例 $(6 \%) ， 13$ 例 $(32 \%) ， 17$ 例（29\%）にみられた。副病果が肝稆 と診断された 86 例 (74\%) のうちMC24例 (28\%)，IM54例 (63\%)， ML8到 (9\%) であった. 術前に存在診断でき，肝㿋と礁診された 17列中16列（94\%）がIMであったのに対し，術後に発現確競された 41副中14例 (34\%) がMCであった.

[結諨] 術前䧐断しえた副病巣径は大きく，殆どがIMであった。 た副病果の $50 \%$ は術後はじめて検出され，術中術後に診断しうるもの ではMC例が增加していた。

索引用語 1 . 肝細胞病 2 . 多発病巣

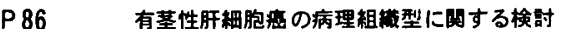

鳥取大学第 2 内科、同中央梌查部”

前田直人、堀江 﨏、孝田雅彦*、加绿誠一、山本暂夫、汐田㓮史、 村䧄意和、周防武昭、川崎宽中

[はじめに] 有茎性肝細胞琶pedunculated hepatocellular carcinoma (PHCC)はEggel分類(1901)に包括しきれないHCCの亜型であり、肝 觔ら有茎性または無茎性に肝外性に発育するHCCで本邦を中心に 约180例の報告がある。PHCCは切除率は高いか吐育進展がきわ て速い点が特行でかか、その病理所見の特徽についてはまとまっ た報告はみられない。今回我々はPHCCの病理像を明らかにするこ とを目的として以下の検乾を行った。

[対象およひ方法] 対象は1983年から1995年までに切除または剖

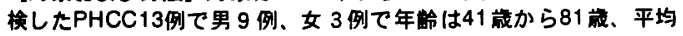
$52 \pm 16$ 殿であり、HBsAg 6 例晅性、HCV抗体 1 例淂性、AFP 6 例 陆性。切除例 7 例、剖湌例 6 例である。組城型はEdmondsonSteiner (ES)分新 (1954)およひWHO分頶 (1978)に华拠して詳細に検 封した。

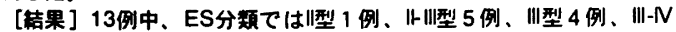
型3例であった。WHO分類では 2 例がtrabecular typeであったが、 11例はすへでcompact typeであった。

[考察およひ結言］PHCCは肝副萧もしくは肝硬变の突出部分から の発生と推測され急速な器育進展が見られるか、今回の梌时ては胴

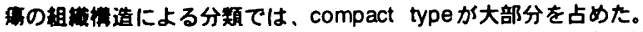
compact typeのHCCは一般に中一低分化型であり悪性度の高いHCC

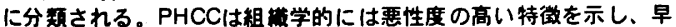
期造断治病切除が行われなければ予後は良好とは言い難いHCCであ ると桔䑳される。

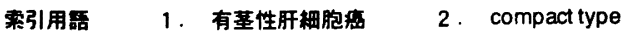
P 87 LIVER TUBERCULOSIS AS A DISTINCT
CLINICAL ENTITY: DIRECT AVIDENCE BY
POLYMERASE CHAIN REACTION (PCR) DE AlcantaraPavawa'' M. Matsumura', Y. Shiratori', T. Okudaira', R. Gonzalez', R. Lopez ${ }^{2}$, J.Sollano', M. Omata'. Second Department of Int. Med., University of Tokyo'. University of Santo Tomas, Philippines? n Asia, tuberculosis has recently increased at an annual rate of $3-6 \%$ (Biegel, 1995). When the liver is involved, the mortality of patients maybe due to severe hepatic dysfunction or portal hypertension. This distinct clinical entity should be differentiated from hepatocellular carcinoma or other granulomatous diseases. While it is ideal to identify the acid-fast bacilli or isolate it by culture, this has been disappointing. The definitive diagnosis of tuberculosis of the liver was based on the histologic evidence of a granulomatous process with caseation necrosis. However, only in $18-83 \%$ of cases can this be detected (Gupta, 1983; Essop, 1984). is the objective of this study is to develop a PCR assay for a diagnostic purpose and correlate it with other available diagnostic modalities to isolate the organism. The target DNA is a 123-bp segment for the first PCR and 63-bp segment for the second PCR of IS6110, which is repeated in M. tuberculosis chromosome and is specific for $M$. tuberculosis complex (Thierry, 1990). Sensitivity of the PCR assay was tested in 15 paraffin embedded liver samples from 13 patients with diagnosis of liver tuberculosis. The specificity of this PCR assay was tested using paraffin-embedded liver biopsy samples from patients with other liver diseases such as sarcoidosis, schistosomiasis and viral hepatitis. PCR was positive in 13 of 15 cases $(87 \%)$ : 9 of the 9 $(100 \%)$ of histologically diagnosed cases and 4 of the $6(67 \%)$ of the probable cases. PCR was negative in all patients with other liver diseases. The PCR system, we developed, is a promising diagnostic modality for liver tuberculosis when the clinical picture or histology are both non-conclusive. 索引用語 1. LIVER TUBERCULOSIS 2. PCR

P 88肝生慔による良性結節 26 例と境界病留 9 例の自然経過 千賲大学第一内科1)、千炛大学第二病理2)、昭和大学豊洲病院3)、

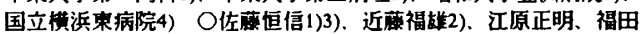
浩之、北和彦、吉川正治、杉浦信之、税所宏光1)、秋池太郎、三木 其4)、正慶修、松川正明、栗原稳3)、近藤洋一郎2) <目的>情性肝疾患にて経過覞察中模出される肝内結䬣性病変にお いて、良性あるいは境界病変の辰期自然経遥を毁察し、画像所見、 病理組满所見と对比する。<方法〉超音波カイド下生恰により良性 病変と部断された肝内結節 26 例 (良性群)、境界病変と影断され 末治原で経過钼察された 9 例（境界群）計 35 列 (全て未治康)に ついて、 retrospectiveに 6 力月以上の自然経過（結飭径の変化、他部

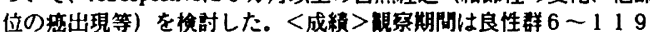
力月 (平均48.6) 、境界病変 6〜5 4 力月 (平均24.3) であった。 蜆察開始時の超音波による結節径は良性群8-20mm (平均11.6)、境 界群6 -16mm (平均11.9) であった。覾察終了後の䊅飾径は、良性群 で㘿大12\%(3/26)。不変38\% (10/26)、描出不明嫄化50\% (13/26)に対 し、境界群で㘿大44\% (4/9)、不変22\% (2/9)、描出不明湆化33\% (3/9) であった。良性群では挒は例はられなかったか、境界群の33\%

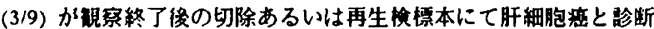
された。なお他部位の期出現は良性群23\% (6/26)、境界群56\% (5/9) に羿めた。良性群 1 例は 6 力月て䄪 2 倍に㘿大した。境界群 1 例は

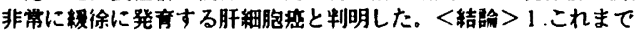

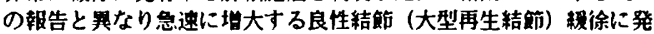
育する境界病変（後に㾀と判明）があった。2.しかし多くの例で 自然経過は生模而見を反映し、生摸にて良性、境界病変を分類する ことが予後の予測に有用であった。3.良性結節で半数の例は経過 中描出不明睹となった。

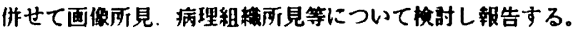

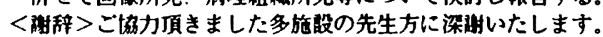
索引用語 1 .大型再生結節 2 . 境界病要 
P 89 FNHの血行動悲に関する検討

久留米大学第一病理

○福倉良彦、中島 収、高粹 努、柳瀨 豊、山本修、神代正道 【目的】Focal nodular hyperplasia(FNH)における血行動態に関する詳 細な检砷は、画像診断や組織発生の点で重要である。今回、我々は、 FNH28結節を画像的、組織学的に、血行動態に注目し詳細に検討した。 【方法】FNHの血行動的を、外科的に切除された25結節において、画像的・ 組織学的に、また、剖検例3結節において、着色ゼラチン造影剤を肝動脈 と門眽より注入し、組織学的に検討した。【結果】組蟣学的に、すへての 結節内には正常の門脈域及び中心㬹脈は認められず、結節内の血管は、 線維生隔壁内に存在する動脈梯筋生血管と毛細血管、実質部に存在す る静脈様の血管の3種類に分類された。また、結節辺縁部には、線維性の 被膜は認められず、結節内の類洞は非結節部の類洞と連続していた。連 続切片における形態学的钼察においては、線維性隔壁内に存在する動 脈様胳性血管は、線維性隔壁内に存在する毛細血管と、また、結節外の 娌眽と連続していた。一方、実䆩部に存在する静脈様の血管は、結節外 の肝觧脈と連続していた。着色ぜラチン造影剤注入による钼察では、肝 動脈より注入した着色ゼラチン造影剂は、線維性隔壁内に存在する動 脈梯筋性血管のみならず毛細血管ならびに線維性隔壁の近傍の類洞に 認められた。画像的には、Angiographyにて、5例に結節をdrainageする と考えられる肝静脈が結節近傍から明暸に描出された。CTAPを施行し た5例全例て、門脈血流は見られなかった。【結論】FNHにおいては、動脈 血が線維性隔壁内の動腺様筋性血管から毛細血管を介して線維性隔壁 近傍の類洞に注き、類洞内の血液は、結節周囲の類洞を介して、もしく は直接肝觧脈に流出する事が推测された。また、結節内における門脈血 流の関与は全く認められず、門脈血流の欠如とそれに伴う代侻性の動 脈血流の過剩供給か、FNHの発生に大きく関与しているものと考えられ た。索引用語：1)限局性結節性過形成, 2)血行動悲

\section{P 90肝境界病変の予後に関する検討}

大阪府立成人病センター第3内科"，同研究所第 10 部 ${ }^{2)}$, 同細胞診断科 ${ }^{3)}$, 同病理検查科

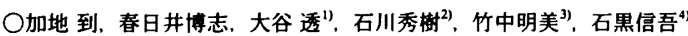

【目的】肝境界病変の取り扱い法を定めるために, 生検細胞診で肝 境界病変と診断された結節の㼭床経過より，その予後を検討した。

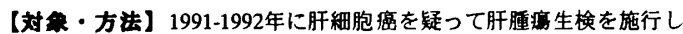
た全症例のうち，無治療で経過钼察されたものを対象とした。肝腫㧶 生倹は，吸引生検法で行い，スメア標本と組織標本を作製した。細胞 診は，スメア標本にPapanicolau染色を行い，われわれの考案したType 分類により判定した。すなわち，Type I(正常)，II(肝硬変)，IIIa(蛏度異 型境界病変), IIIb(高度異型境界病変), IV (高分化型肝細胞癌)およびV (中分化型ないし低分化型肝細胞㿋)の6型である。症例は1996年7月ま で経過を钼察し、経過中の肝紐胞癌の発生の有無を検討した。【結

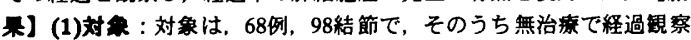

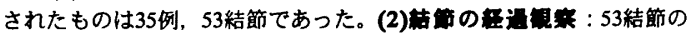
4年目の累稖肝紐胞㾂発生率は，細胞診判定Type $\mathrm{mb}(\mathrm{n}=8)$ では $50 \%$ 之,

Type Iまたは $(\mathrm{n}=19) の 8 \%$ ，Type 桼a(n=15)の17\%に比べて有意に高率

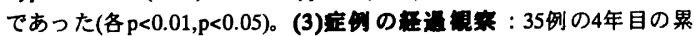
䖽肝細胞看発生率は，細胞診判定の最高異型度がType IIa(n=10), Type $\mathrm{mb}(\mathrm{n}=7)$ の症例ではそれぞれ67\%，58\%と，Type IないしIの症例 $(\mathrm{n}=14)$ の $28 \%$ に比へて高率の傾向があった(各NS,p<0.05)。【䋨田】 (1)細胞診判定がType IIIbの結節では，肝細胞癌の発生が高率に認めら れることより，敞重に経過観察が必要であり，PEIなどの加瘘も考虑 されるべきと考えられた。(2)細胞診判定がType 血正上上の結節を有す る症例では，对象結節以外も含めて肝細胞癌の発生が高率に認められ ることより，肝全体の敞重な経過稓察が必要と考えられた。

索引用語 1 . 肝境界病変 2 . 予後

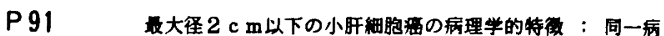
变内の分化度と紏胞㙩殖能の heterogenity の检祄

山梨医科大学第一外科

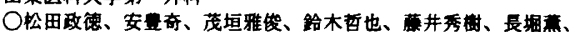
松本由朗

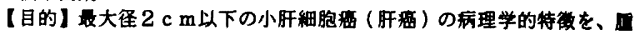
内の分化度と絧胞細胞堵致能の heterogenity の点加ら明らかとする ことを目的とした。【方法】1992年3月から1996年9月までに 当科で切除され、良好な摆本が得られ、をの病变加原発と考えられた小 訮病を持つ9症例 (男性 4 人、女性 5 人、jち 1 例は同時性多中心性発

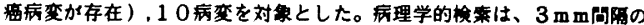

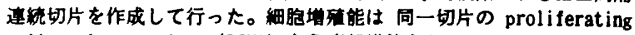
cell nuclear antigen (PCNA) を免度組織架色し、labeling index (LI)

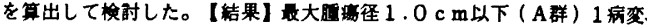
$1.1-1.5 \mathrm{~cm}$ (B群) 5房変、 $1.6-2.0 \mathrm{~cm}$ ( C群) 4 病変 あった。被殿形成はA 群なし、B群40\%、C群1 $00 \%$ であり、被展

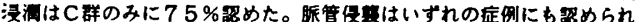
なかった。肝内枟移はC群の1列（25\%)に被められた。A群仕全体 加高分化旰盘であったか、B群、C群ではすへての病変内に中分化以下

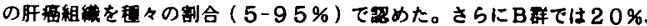
C群ではすへての房变内に低分化肝癌か存在した。PCNA-L1は、离分化 肝㾇で 0.7-2 7.6\% (平均 $10.8 \%$ )、中分化肝盘で 0.8-52.3 $\%$ (平均 $20.5 \%$ )、低分化肝婹では $10.8-75.5 \%$ (平均 46.2

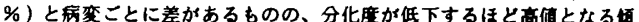
向を珰めた。同一病変内でみると、すべての病变で分化度が低下した部

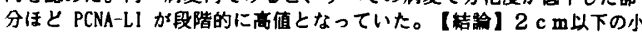

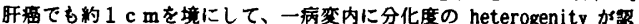

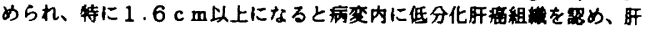

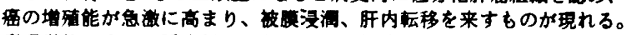

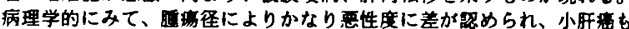
より細分化して检㣙する必要加あると考えた。さらに、一つの底变内て

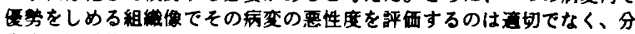
化度や墙殖能の heterogenityをも考虑する必要があるものと考えた。

繁引用語 1. 小肝細脂癌 2 . heterogenity

\section{P 92}

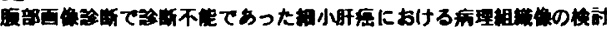

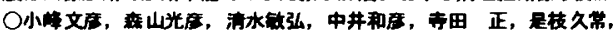

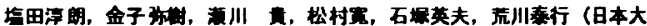

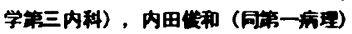

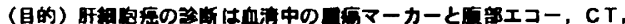

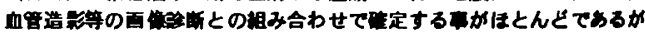

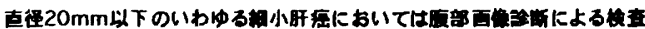

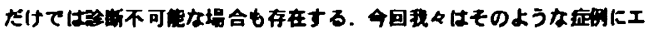

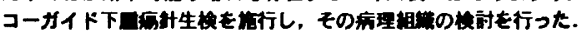

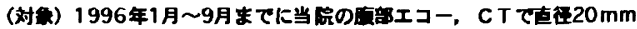

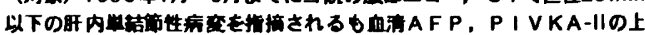

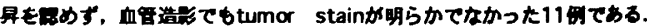

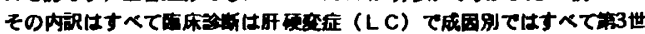

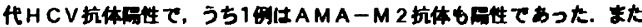

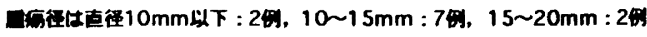
てかった.

(方法) 全症田にエコーカイド下新生 (シュアーカット18Gまたはオ

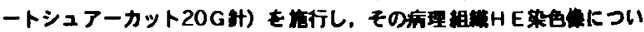
て蝻耐した.

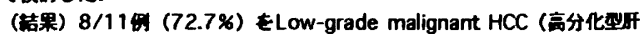

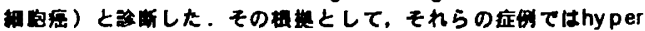
cellularity, different cytoplasmic stainning, frequent acinar

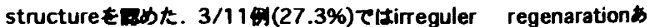

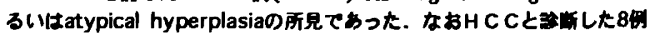

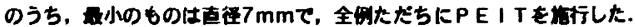

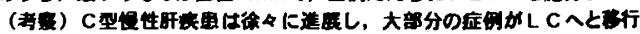

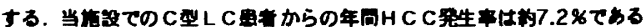

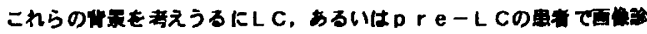

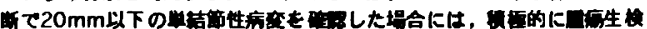

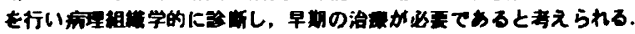

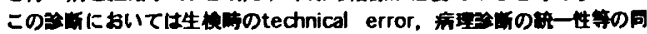

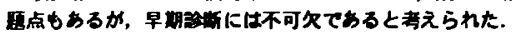
整引用通 1.Low-grade malignant HCC 2. 


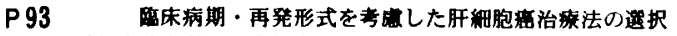
名古屋这病院内科○堀米秀夫, 藤野信男, 村崎元五 增子記念病院内科公瀨昭意

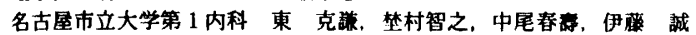
【目的】肝細胞蓄( $\mathrm{HCC})$ は治療後も高率に再発をきたし，再発形式に より予後が異なる．また，HCCがコントロールされていても肝不全で 死亡する例がみられ、陁床病期も予後を左右する重要な因子と充方ら

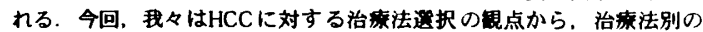
予後について庑病期・再発形式から検时を行った.

【対象・方法】治案後の経過覞祭が 1 年以上なされ、治瘘により病変 が画揀上もしくは組織上治构したと考えられるHCC85例を対象とし， 脏底期 (CS) と治療法, 再発形式別にそれらの予後について検封した。 なお，治㙩法は肝切除(43例)，経皮的エタノール注入㠃法 (PEIT，18例)， 経皮的マイクロ波凝固䕛法 (PMCT, 13例)，肝動脈塞栓術 (TAE，11例) の4撯间で，再発形式は異時性多発再発 $(\mathrm{MC})$ と肝内転移 (IM)の2群に分 類し, 比校検討した.

(成䋖) (1) 再発は60例 $(71 \%)$ と高率にみられ，再発形式はMC21例(35 \%), IM39例 (65\%)であった. (2) IM例はMC例に比䡈して予後不良であ り，その差はCSI期で著明であった．(3) CSI期は33例中23例 (70\%)に肝 切除が施行されており，肝切除例は再発してもMC型が多く $(71 \%)$, 非 切除例に比较して予後が良好であった. (4) CSII期では肝切除例のIM型 再発は61\%でありPEIT例 $(73 \%)$, PMCT例 $(80 \%)$ に比べ少なかったが 肝不全死亡例が11例中7例 $(64 \%)$ と多く、3群間で生存率に有意差はみ られなかった. (5) TAE例はCSにかかわらず高率にIM型再発をきたし 予後不良であった.

【結詥】CSI期は可能な限り肝切除を，CSII・ II 期は内科的治療法を第 一に選択すべきものと考えられた．ただし，TAEは単独ではなく，果 学的治寀の一器として行うのが望ましいと考える.

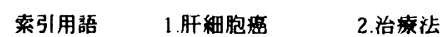

\section{P 94} 整大学第2内秙

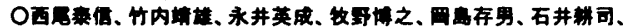

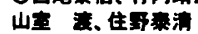

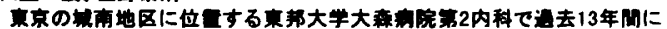

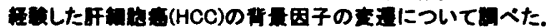

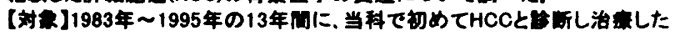

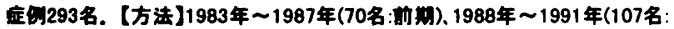

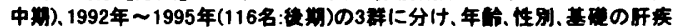

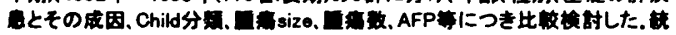

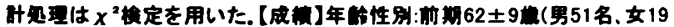

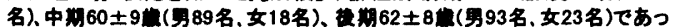

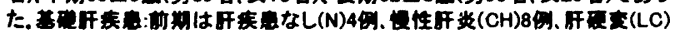

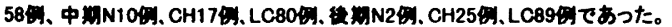

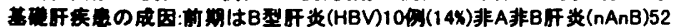

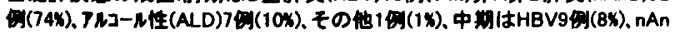

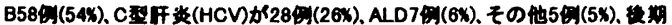

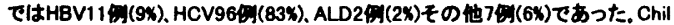

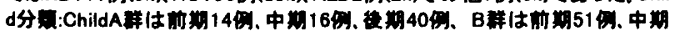

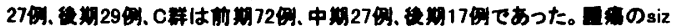

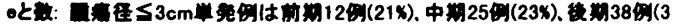

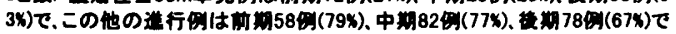

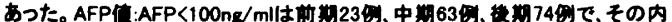

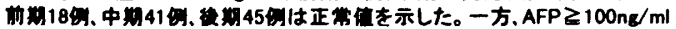

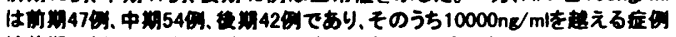

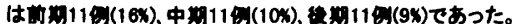

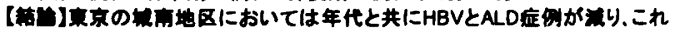

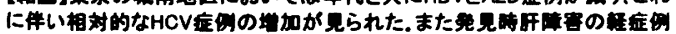

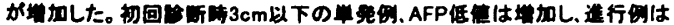

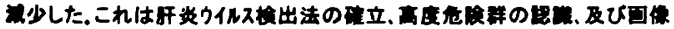

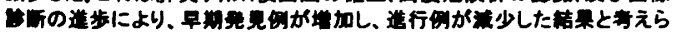

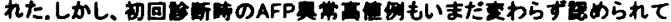

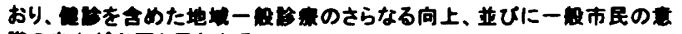
城上がめ更と思われる。

察引用部

1. 所武

2. 静觜因子

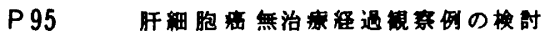

争岡累立就合府院消化器科

○西 俊希、伊東和樹、小野川嗉二、松谷密政、竹清英夫、 西村倞司、梅田容弘、木田実、松田目幸、小岛梳一

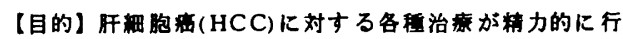
われてきたが、これらの治家が患者にSurvival Benefitをも たらすことを明確に示した報告は少ない。HCC治裳の意

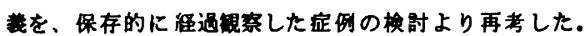

【対象と方法】遇去13年间の新鲜HCC 664 例中、保存的 察法 (BestSupportive Care, BSC)で対処した100例（15.1\%) を対象とし、BSCを選択した理由をretro-spectiveに捅析す るとともにKaplan- Meler法による生存率を算定した。

【結果】BSC選択の理由は、発見時HCC遇進展-肝不全】 PS不良 73例、肝硬变-低肝機能/HCC以外のLC合併症 14

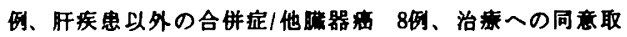
得不可5例であった。大多数が高度進行HCCであったが、 高度硬变肝に発生した細小HCCも一部含まれた。入院日 からの生存本は、6か月 $13.4 \% 、 1$ 年 $7.5 \%$ て $50 \%$ 生存期 間は40日、最長生存は690日であった。

【考察】進行HCCではBSCにて2年以上生存する例が皆無 であった一方、高度硕変肝+細小肝船例では、死亡の時

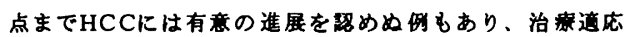
決定にあたっては、定例ことに予後規定因子を十分考虎 すべきである。

索引用語 1.肝細胞来 2.自然经遇

P 96 肝稩胞疾の診断と治療における侵性肝庫害患者の経遇 舅察の評価

千菜大学第一内科

○杉浦信之, 天野 晋, 透藤恒宏, 片平裕次, 波多野良二, 森本

直湖, 真田昌彦, 福田浩之, 吉川正治, 江原正明, 税所宏光

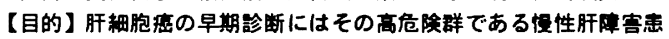
者を定期的に経遇穓窥することが重要とされている。そこで，慢性

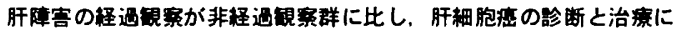
どのような意臆がられたかを検討した。

【方法】1985.1-1996. 9の間に千菜大学第一内科で肝細胞痘と眕断さ れ. 当科で初回入院治痛を受けた症例は503例（男性407例，女性86 例，平均年鲙59.9歲) である。そのなかで，千葉大学第一内科で1年

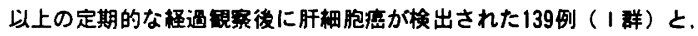

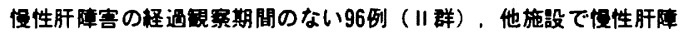

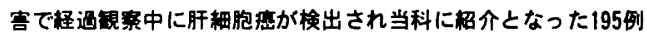

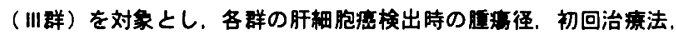
予後を検討した。

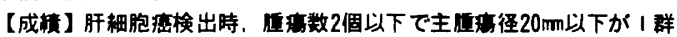

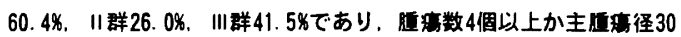
mm以上の症例はそれぞれ16.5\%,57.3\%,34.0\%であった。肝辎胞疼に対

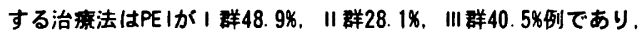
TAEとTAE-PEIあわせてそれぞれ33.1\%，34.3\%，43.6\%、リザーパーを

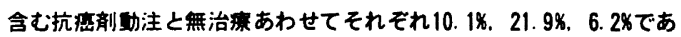

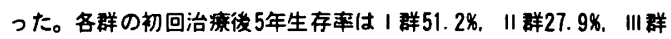
40.2\%であり，死因は痕死がそれぞれ66.0\%，64.0\%，55.9\%であった。

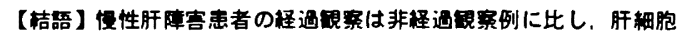
疾が有意に小值㾂で検出され，治療後5年生存率も高かった。

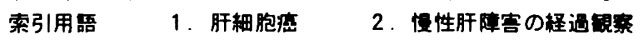


P 97 HCV-RNA狯性:HCV抗体陽性.朋瘦の検討

闺束违信病院消化器科*。煺康管理科**

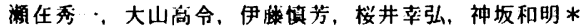

安部萃, 池上文哭 $* *$

目㐻）近年(型朋炎のインターフエロン（IFN)治燎による完全 完解後の朋細胞瘦発症についての拉例報告が散見される。一方IFN 歴のないC型时症治潦例のうち血中HCV-RNAが持絖的に䧔性である 症例も存任するため検討をおこなった。

対象，方法）第 2 世代HCV抗体陽性（全例cut of $\mathrm{f}$ index6.5<), HCV RNA(PCR 法) 陰吽, HCV-RNA(プロープ法) 0. $5 \mathrm{Meq} / \mathrm{ml}$ 术滥であ

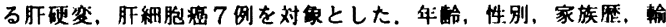

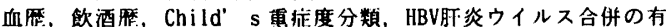

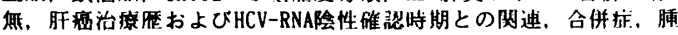
症マーカー，血小板、朋組織HCV-ブラス銷RNAについて榆封した。 結果）平均年齢 64 才，男性 5 例，女性 2 であった。家族歴で肝 疾热例は 3 、陯血歴 3 のうち大量輪血例 2 ，HBV朋炎ウイルス合併 例はいなかった。朋艀の数は多発型 2,3 個 1,2 個 3 , 単発 1 であった。治摬歴はTAEが全例に施行されており，平均 2.4 回て あり，使用来剂は 1 回平均 $\mathrm{ADM}^{\mathrm{R}} 20 \mathrm{mg}, \mathrm{MMC}^{\mathrm{R}} 10 \mathrm{mg}, \mathrm{LPD}^{\mathrm{R}} 6 \mathrm{ml}$ ，PEIT併 用例は 4 例で平均総エ夕ノール使用且は $53 \mathrm{ml}$, 朋㾇切除 1 。 直達術・摘脾 1 , 経内影婙脈性朋内門脈朋静脈シャント術 1 であ った。初回朋㾇治境からHCV-RNA陰性確認までの期間は 34 力月

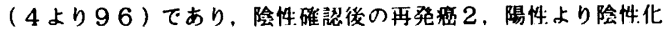
が迫跡し得たのは2であった。

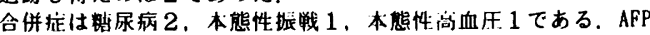
はピーク時 $1739 \pm 1010(\mathrm{M} \pm \mathrm{SE}) \mathrm{ng} / \mathrm{ml}$, PIVKA-2は 6 例正常、1 1 例 がピーク時 $6.06 \mathrm{AU} / \mathrm{ml}$. 血小板は初回発楆将8.5 $1.0 \times 10^{1} /$ $\mathrm{mm}^{3}$ であった.相組緎HCV-ブラス鎖RNAは 2 例とも陰性であった。

結語）朋原因としてHCV抗体陽性による祅断法では解釈しえな い1前の存仕が明らかになり、HCVによる肝発㾞機櫣を解析するに あったて興味のある現象である。

索引用詰) 肝細胞楼, HCV-RNA

P 98

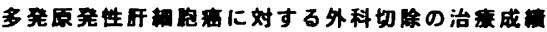

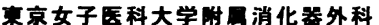

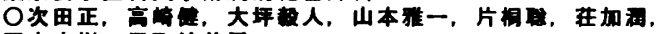

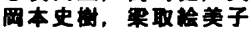

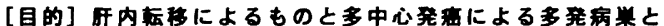

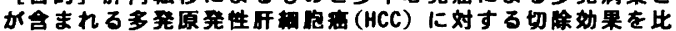
鼓封した。[対象と方法] 1990年から1994年までに所切除 を行なったHCC 应のうちVp2 以下かつVv2 以下で街前治康

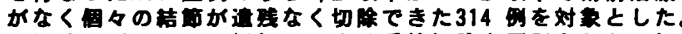
所切除はクリンンー括奶理による系新切除を原則とした。切 除本上の络々の落笛のHE所見において, primary かSeco

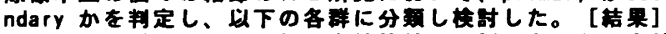

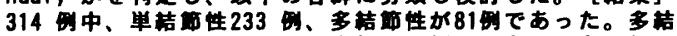

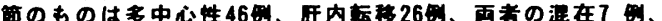
判定不能2 に分新できた。非票部の性状は多中心性では所

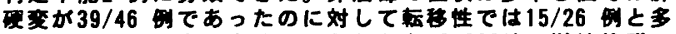

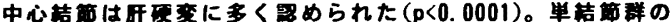

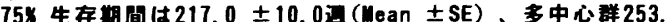

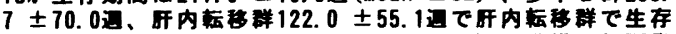

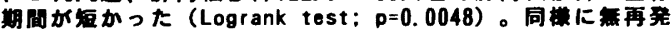

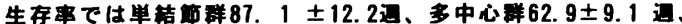

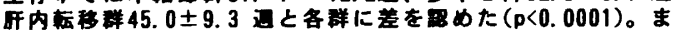

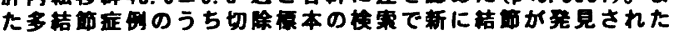

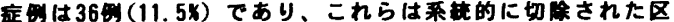
域内に存在していたものであった。[まとめ]多政策性のHC

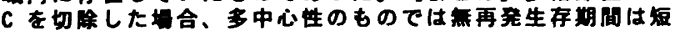

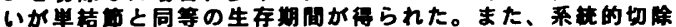

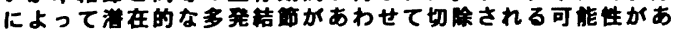
ることが示された。したがって衙前には多中心と所内枟移を

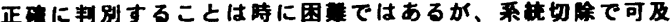
的に多発病紧を切除することは意新のあることと考えられた。

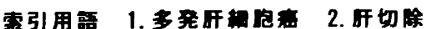

P 99 校模沽

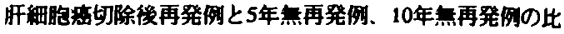
兵庫医科大学第一外科 ${ }^{11}$ ，同病院病理2)

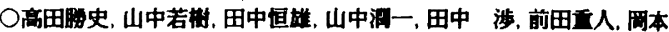

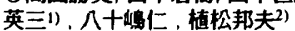

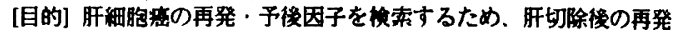

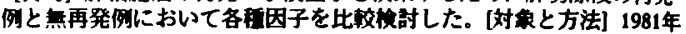
1月 1990年12月に施行された在院死を除 382例のうち、術啳 1 3 年再

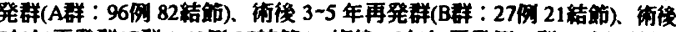

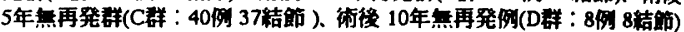

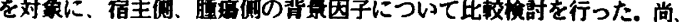

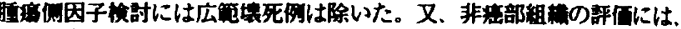
Knodell 5 の Histological Activity Index (HAI score) を用いた。[結果] 宿

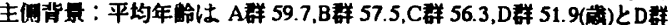
で低く、C群、D群における女性比が 6/40(15\%),3/8(37\%)とやや漓かった。 HBs-Ag(+),HCV(+)は各群に差は繁かった。A群,B群に钦酒歷を有する

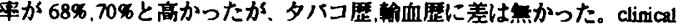
stage I の頻度がD群で 88\% と有意に高く、GOT(GPT)もA群 59.5(63.3),B 群 51.6(64.4).C群 66.2(74.4).D群 37.3(41.6)とD群で有意に低かった。待

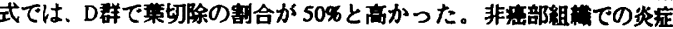

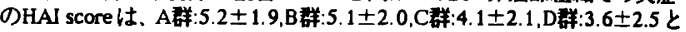
再発時期が早いほど炎症度が強く、無再発期闪の長いほど炎症度の朋 い傾向が認められた。睡通侧背景: 分化度では、D群で高分化型が50

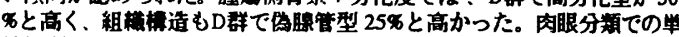

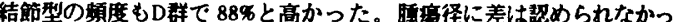

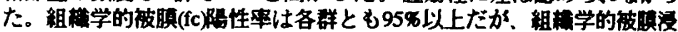

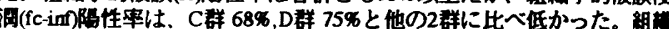

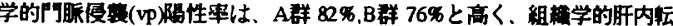
移(im)朐性华は、D群のみ12\% と低かった。肉眼的進行度(stage)では。

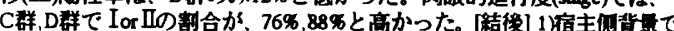
は、予後良好例に女性の占める割合が高かった。 2)背䭪肝では、炎症 の程度が強いほと再発時期の早い項向が规められ、每再発群では年再

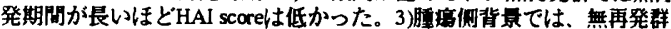
で fc-inf(+).vp(+)の頻度は少なかった。

索引用离 1.10 年無再発 2.HAI score

P 100 肝細胞癌切除後における断端再発率からみたCautery with Irrigation Forcepsの有用性および残肝断端に与える影留に関する検討 山口大学第 2 外科

○高尾康一郎、西田蜂勝、前田義隆、高尾貫史、岡 正朗

【目的】我々はCautery with Irrigation Forceps(CIF)の使用で、残肝に対 しては無阻血下での肝切除が可能となり、より低侵到であると報告し てきた。今回、その使用経験が 3 年を経過し、CIFを使用しなかった 症例（主にCUSAにて肝切噰を施行）と比較し、断端再発の有無を中 心にその有用性を検討し、さらにCIFの残肝断端に与える影零に閲す る実験的検討を行ったので報告する。【対象および象䋡方法】当科で 経铪した肝細胞癌切除例の内、他病因死、絶対非治䒴切除、 $\mathrm{V} p 3$ 症例 を除く耐術症例118例を対象とした。実検に関しては、ドンリュウラ ッ卜を使用し内側葉を結禁切除後、外側葉を切除。その切除用器具に より CIF群 : CIF、IB群 : Irrigation bipolar、を作成した。初回手術終了 後、各群とも第1、2、3、7、14日目に再開腹を行い胿切離面の梌索を 行った。【結果】䀒切離に際し、CIFを使用した症例 (CIF群) 38例、 CIFを使用しなかった症例 (CUSA群) 80例でちった。CIF群の1年、2 年累皘生存率および無再発生存率は、それぞれ96.4\%、91.8\%および 82.9\%、68.0\%であり、CUSA群のそれは、それぞれ93.8\%、81.2\%お よび67.5\%、48.2\%であった。CIF群において累稓生存率お上び無再発 生存率ともに良好な傾向を示したが有意差は認めなかった。再発を来 したものはCIF群で10例、CUSA群55例であった。肝切雄面にのみ再発 を来したものを明らかな断端再発とし、CIF群で2例(5.3\%)、CUSA 群で8例(10.0\%)の断端再発を認めた。また、切除標本のTW（取り扱い 规約に準ず) から検郡するとCIF群ではTW $(+)$ 16例中2例 (12.5\%)の 断端再発を来し、TW(-)22例では断端再発は認められなかった。CUSA 群はTW(+)44例中6例 $(13.6 \%)$ の断端再発を来し、TW(-)36例におい ても2例 $(5.6 \%)$ の断端再発を認めた。実験においては残存側外側菜 の肉眼的焼妁距耀はCIF群とIB群間に有意差を認め、より十分なTWか 得られることが確認された。【考察と結語】CIFの使用経掺は3年にす ぎなか、CIFを使用することによって低侵筫の肝切除に加え、術後 早期における断端再発率の低減、ひいては予後の改善にもつなかる可 能性が示唆された。TW(-)であっても切除断端近傍の盘遗残は十分考 えられ、CIFはIrrigation bipolarと比較し十分な㹸灼城が生しることか ら、肝切離断端の監遣残を防止できるものと考えられた。 索引用語 1. CIF 2 . 


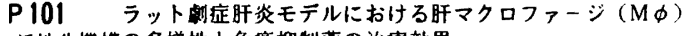

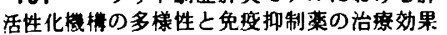

'埼玉医科大学第三内科, ${ }^{2}$ 東京大学第一内科

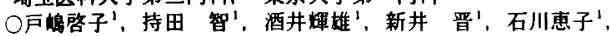
池田 均1.2. 松井淳 1 、藤原研司 ${ }^{1}$

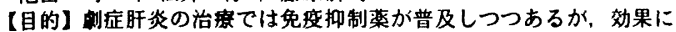

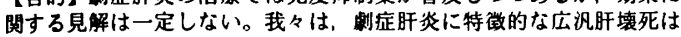

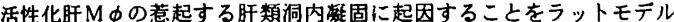
て証明した。また，䀒M $\phi$ の活性状態はモテルにより多棣で，類洞内 标固の成立機序にも差異が存在することを明らかにした。従って， 症䀒炎に対する免度抑制薬の治効果も䀒 $\mathrm{M} \phi$ の活性状態により異な

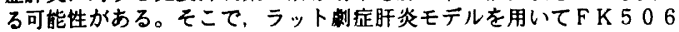
の治效果と肝 $\mathrm{M} \phi$ 活性化機構との関連を検討した。【方法と成結】 C. parvum死菌投与 7 日後または $70 \%$ 旰部分切除 48 時間後のラット にLPSを静注して肝障害を誘発した。(1)治噔実䟻：LPS 静注 24 時間前にF K 506 を筋注すると, 死菌モテルの旰障害は轻減したが 䀒部分切除モテルでは改善しなかった。(2) Northern blotting : 死菌 モテルでは C. parvum静注 5 日後をピークに, 旰の I F N $\gamma$ Inducing Factor (I G I F) 及び脾の I F N $\gamma$ 発現か高度となり，7 日後の䀒 及び単離盰M $\phi$ でCD 14 発現が增強した。盰部分切除モテルでは, 12 時間後より肝の I G I F 発現か軽度上昇したか，脾における I F $\mathrm{N} \gamma$ 発現や，䀒M めのCD 14 発現增強は見られなかった。死菌静注 6 日後に F K 506 を投与すると， 7 日後の肝におけるC D 14 発現 は怪堿した。【考案】死菌モテルの肝M $\phi$ は T N F $\alpha$ や活性酸素を故 出し類洞内皮細胞を障害することにより類洞内疑固を誘発する。この 䀒M $\phi$ 活性化は I G I F. I F N $\gamma$ 系を介してLPS受容体であるC D 1 4 の発現が增强することにより起こるか，FＫ５０６はこの過程 を抑制し盰障害を睛隇すると考えられた。一方，盰部分切除モテルの 肝M $\phi$ は渴管からの bacterial translocationで活性化し, 組織因子 活性加著增して類洞内擬固を惹起する。この過程では I G I F・I F $\mathrm{N} \gamma$ 系は作動せず，肝M $\phi$ のC D 14 発現も增強しない。また，この 型の䀒障害には，F K 506 は無勃であることが判明した。【結語】 ラット㱏䀒炎モテルに対する F K 506 の有効性は䀒M $\phi$ の活性化 機權により異なり，胍症旰炎に対して一律に免投抑制菜を投与すへき でないと考えられた。(索引用語：1。劇应䀒炎 2.FK 506 ）

P 102 カラクトサミン(GalN)誘発急性肝不全におけるKupffer細胞 およひ脾macrophageの機能とアボトーシス

奈良県立医科大学第三内科

O北方一成、北野浩行、長本一成、中谷吉宏、菊池英亮、松本昌美、 菊川政次、辻本達寛、高谷 章、福井 博

【目的】急性肝不全では、エンドトキシン(Et)なとの剌激下に活性 化macrophageからサイトカインを含む肝細胞障害性のchemical mediatorsが週剩分论され、肝細胞のアポトーシスア広䡩肝㧼死の 発現にかかわるとされているが、その詳細は明らかでない。われわ れはラットGalN急性肝不全モデルにおいて、Kupffer細胞、脾 macrophageの機能とアボトーシスの発現過程について模討した。

【方法】 in vivo. SD系雄性ラットにGalN(1000mg/kg i.p.)を投与 し、経時的に血中Et、ALT、TNF- $\alpha$ を測定し、盰組樴変化と TUNEL法によるアボトーシスの発現を钼察した。in vitro GalN投 与前、投与後1,3,6,12時間に訮Kupffer細胞、噌macrophageを分嚾。

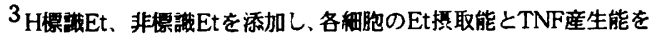
検矿した。【成績】 in vivo: 血中EtはGalN投与直後より著増して3 時問後に最高値をとり、TNF- $\alpha$ は3時間より、ALTは6時闑より增 加した。肝細胞のアポトーシスは6時間より钼察され12時間でピー クとなり、以後肝細胞境死が進行した。 in vitra. Kupffer細胞のEt 提取はGalN投与1時間後に著減し、その後も低値を示したが、 $\mathrm{TNF}-\boldsymbol{\alpha}$ 産生は1 3 3時間後に一時的に增加した。一方、胳 macrophageのEt摄取はGalN投与3時間後をビークとして著增し、 TNF- $\alpha$ 産生も経時的に增加し䌇けた。【結語】GalN急性肝不全モ テルでは血中Et、TNF- $\alpha$ の上昇に続き、アポトーシスの誘導が認 められた。アポトーシスの誘導にかかわるとされるTNF- $\alpha$ は主と して脾macrophageに由来し、Kupffer耕胞の関与は初期に限られる ことが示唆された。

索引用諲

$$
\text { 1. アポトーシス 2. TNF- } \alpha
$$

P 103 TNF- $\alpha$ による肝細胞死の誘導作用 : Fasシステムとの対比 吱阜大学第一内科 ○永木正仁、杉山昭彦、森脇久隆、武藤泰㙁

[目的] 近年、TNF/TNF受容体とFas/Fasりガントを介するシステム が多くの細胞にアボトーシスを誘導することが知られている。肝細 胞死におけるTNF- $\alpha$ と Fasシステムの作用機楼に聞して実駼的検討を 行った。[方法] (DBALB/cマウスにTNF- $\alpha$ よび抗マウスFas抗体 を単独並びに少量のD-galactosamine (GalN) と併用して腹腔内に投与 し、血清GPTおよび肝組織所見を検討した。(2)GalN, TNF- $\alpha$, GalN+ TNF- $\alpha$,Fas抗体をマウスに投与し (TNF- $\alpha$ は静脈内投与)、経時的に血 清GPTを湘定し肝組䋨をTUNEL法にて染色した。また、肝における TNF受容体 (TNF-R) 55 mRNAおよびTNF-R75 mRNAの発現をノーザ

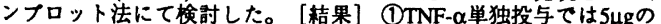
投与にてもGPT値の上昇は認められなかったが、GalNと併用により $0.5 \mu \mathrm{g}$ て $623 \pm 187 \mathrm{IU} / \mathrm{L}$ と GPT值の上梨加認められた。Fas抗体単独: 1 ,

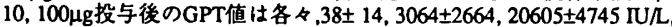

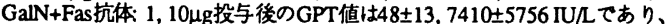
TNF- $\alpha$ に比してGalN併用による肝障害の增強作用は著明ではなかっ た。GalN+TNF- $\alpha$ およ゙゙Fas抗体投与後の肝組織は、而者とも広箅な 出血性肝細胞死の像がみられ、電顕においてて胿細胞に核クロマチシ が核膜に沿って凝集しておりアボトーシスに特徽的な所見が認めら れた。(2) GalN+TNF- $\alpha(0.5 \mu \mathrm{g}$, iv) 投与 $3,5,8$ 時問後のGPT值は $53 \pm 10$, $1276 \pm 318,15117 \pm 4524 \mathrm{IU} / \mathrm{L}$ でった。同時に肝組織をTUNEL法にて 染色したところ、GPT值が上昇していない3時間後において既に肝細 胞にアボトーシス細胞が認められ、5時間後にはその数は增加した。 GalN並びにTNF- $\alpha$ 単独投与てはGPT值の上年は証的られずフポト シス細胞も全く認められなかった。Fas抗体投与 1,2,3時間後のGPT 值は $30 \pm 10,5583 \pm 3328,11433 \pm 5151$ ГU/Lであ $\eta 、 G a l N+T N F-\alpha に$ 比較 して早期に肝細胞障害が惹起された。(3TNF-R75 mRNAは、GalN単 独およU゙GalN+TNF- $\alpha$ 投与マウスにおいて経過中肝において発現が著 明に增強していた。一方、TNF-R55 mRNAの発現には有意差を認め なかった。[結語] TNF- $\alpha$ よびFas抗体はともに、肝細胞にアボト ーシスを契機として肝に広籍な出血性肝細胞障害を惹起した。TNF-

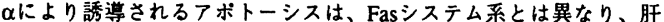
細胞がGalN等により sensitizedされることが必要であった。GalNによ る肝のsensitizationには、TNF-R75が誘導されることが重要であると 考えられた。

索引用語 1 ・アボトーシス 2 . TNF受容体

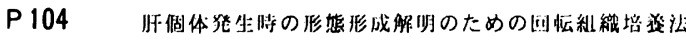
について 京都府立医科大学第三内科

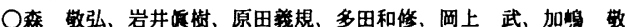
【目的】障客及び切除後の肝再生の形娊形成について梌㣙した報告は 少ない。今回我々は、增殖・分化過程にある胎生期・生直後のマウス 肝を回枟培䖭に供し、旰組䋊の形怒形成解明における本法の有用性を 検討した。【万法】胎生中期、後期と生直後のD D Y マウスの肝瞙を、 米冷した Gey's Balanœd Salt Solution (GBSS)で洗浄し、ティシュー チョッパーを用い厚さ $400 \mu \mathrm{m}$ に薄切後、実体影改鏡下で $1 \sim 3 \mathrm{~m}$ m四方の切片を作成した。同切片を GBSS 30 分間氷椧し、カパー クララストてブラズマクロットに包埋させ、Eagles 沎、Hanks 波、牛血 清の混合培液中に入れ.3 $7^{\circ}$ C恒温槽のローテーターで回枟培爰し、

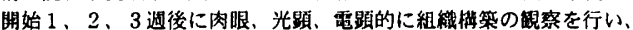
抗アルプミン(ALB)、抗 $\alpha$-fetoprotein(AFP)及び抗サイトケラチン (CK) 19 抗体を用いた免废組䋨化学法にて、师細胞及び胆管上皮細胞 の同定を行った。【結果】胎生中期、後期と生直後の所組織は、肉哏 的に数層からなる紐胞集坮を形成し、集熄は $1 、 2 、 3$ 週後に伸展、 溥屏化した。光影的に集塊居辺は間啠系細胞が見られ、その中心部は 造血采細胞と多角の細胞が混在していた。胎生期の緗胞は、AFP反応 阳性を示し、島状に見られた。生遖後の組胞は察状满造を形成し、ALB 反応陽性を認め大超微形照的に ALB 反応は粗面小胞体や核膜周囲䶼 に見られ、円形の核と辢䈏な粗面小胞体やミトコンドリアを認めた。

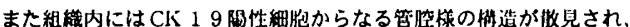

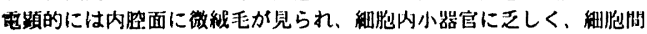
によく発野した tight junctlon を琶めた。【結語】做体発生洔のマウ 不肝を用いた回枟培法は、肝組胞之胆管上皮細胞の同定及び組䋨推

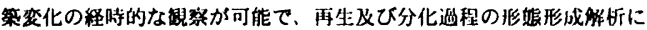
有用と籽えられた。

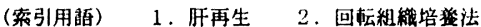


P 105 Kuppfer細胞を介したparacrine機構による肝䐙同時 切除術後の肝再生㧕制

東北大学第 1 外科

○内山哲之、鈴木正徳、海野倫明、力山敏榯、福原棸治、松野正䄫 【目的】我々はラット肝脺同時切除モデルを作成し肝再生が抑制さ れることを明らかにしてきた。今回この抑制機棈を解明すべく、 Kuppfer細胞（KC）を介したparacrineによる肝再生抑制の実験的 検討を行った。

【方法】SD系雄性ラットに70\%肝切除（Hx群）、70\%荤切除（Px 群)、70\%肝切除 $+70 \%$ 膀切除 (Hpx群) を施行し、術後1時間後の 門脈血清を探取した。肝細胞とKCの混合培恙(1:4)を行い、各群の 血清で刺激した後、 ${ }^{3} \mathrm{H}$-thymidine取り込みによるDNA合成能を測 定した。また血清をKC培恙液に加え48時間培美後上清を回収し、 肝細胞培養に加えDNA合成能を測定した。

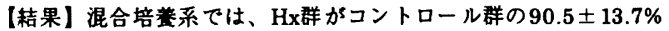
に対し、Px群では91.0土6.3\%と有意差を認めなかったか、Hpx群 は34.7士 10.4\%と有意に抑制された。またHpx群で刺激したKC培

盖上清による肝細胞のDNA合成は $38.0 \pm 5.8 \% に$ 抑制された。

【結語】肝膦同時切除群はKCを介したparacrineにより肝再生が抑 制されていることが明らかとなった。また牶切除のみでは効果を発 現しないことより、腪由来の增殖因子の減少のみではなく訮䐙䐵器 相関による可能性が考えられた。
索引用語
1.肝再生
2.抑制機桡

P 106 急性肝不全における ALR(augmenter of liver regeneration)の肝 再生機序についての检討

○谷川幸治, 増原昌明, 田村興子, 山下智省, 坂井田功, 村上不二夫*, 安永満**，萩屋道雄***，沖田極

山口大学第一内科, “同総合診療部、"*町立大和病院。"**東洋紡績医薬 研究所

目的 : NK細胞はラット障害肝で再生肝細胞に障害性を持つ.一方FK506 等の免疫抑制剂は IFN- $\gamma$ を介して NK紐胞活性を抑制し肝再生を促進す る. 萩屋らは肝細胞增殖活性をもつ幼若ラットサイトソル抽出物, HSS (hepatic stimulator substance)をさらに精製，クローニングし ALR と命名し た. 我々はＡLRのヒト障害肝における肝再生への関与を検討するため に, 肝疾患患者の肝租織中 ALR mRNA, 血清ALR 值, 未梢血 NK細胞活 性を測定した. 方法 : 対象は急性肝炎 4 例, 急性肝炎重症型 6 例，劇症 肝炎 4 例, 慢性肝炎 14 例, 慢性肝炎急性增要 2 例, 肝硬变 5 例, アルコ 一ル性肝障害 1 例, 脂肪肝 1 例である. 血清ALR 值はEUSA 法, 肝組織 中の ALR mRNA はcompetitive RT-RCR，NK細胞活性は ${ }^{51} \mathrm{Cr}$ 遊猚法を用

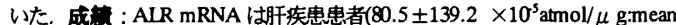
$\pm S D . n=29)$ で健康コントロール(16: $n=1) に$ に比し高値であった．血清 ALR 值 は急性肝炎重症型，劇症肝炎 $(183.0 \pm 128.5 \mathrm{pg} / \mathrm{ml}: \mathrm{n}=8$ )で健康コントロール $(15.4 \pm 8.1: \mathrm{n}=10)$ と比し有意に上昇していた $(\mathrm{p}<0.05:$ Mann-WhitneyのU検

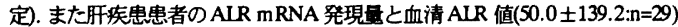
には正の相関関係か膠められた $(n=29: \rho=0.38: p<0.05:$ Speaman の順位 相関). また急性肝炎重症型，劇炡肝炎で血清 ALR 值と末梢血 NK紐胞话 性(32.0土19.8\%:n=8)の間には負の相関関係か鼠められた(n=8: $\rho=0.76$ :

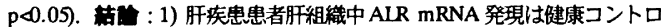
一ルより上型しており，かつ血清ALR 值と正の相関関係を認めることか ら，ALR は肝障害時に肝婼で産生され，末梢血中のALR 湌度に反映され

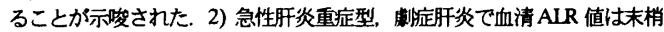
血中NK紐胞活性と負の相関を示しており，ALR は比重症肝障害でNK 紐胞活性抑制によって肝再生を促進している可能性か祘唂された。 索引用語 1.ALR 2.肝再生
P 107 ヒト依性所炎およひ肝硬变における血管新生とVasculer Endothelial Growth Factor (VEGF) の発現

1) 大阪市立大学医学部第二争剖、2) 周第一病理、3) 同第二扊理 、

4) 北野病院外科

○小島明子 ${ }^{1)}$ 、上田真喜 $7^{2}$ )、牧 影井幹已 ${ }^{3)}$ 、金田研司1)

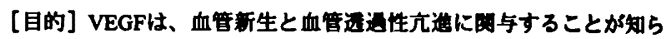

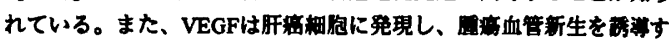
ろことが明らかにされている。しかしながら、ヒト传任肝炎や肝硕 におけろVEGFの発現とその意意については未だ不明な点が多い。本 研究では、ヒト僈性肝炎や肝硬变における VEGFの病照生理学的意 を明らかにするために、VEGFの発現を兔度粗灣化学的に柃村した。

[方法] 剖検およひ訮生梌より得られた25例の肝組流を解析した。用

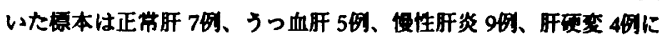

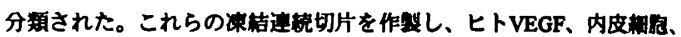

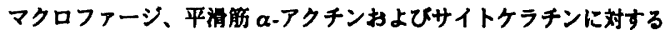

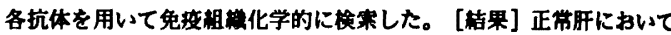
VEGFは、一部のKupffer相阅に発現していろのみであったが、うっ血 肝ではVEGF愓性Kupffer料胞の数は増加していた。これに対して、传 性肝炎や肝硬变の症例では、VEGFはKupffer糊胞のみならず、グリソ ン解の肝内血管枝の内皮梱胞にも発現していた。さらに炎症榦に存在 する多くの新生血管の内皮絊胞にも、VEGFの明らかな発現が眼めら

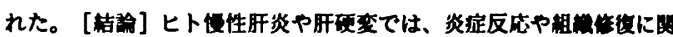
通する血管新生において、VEGFが重要な役剖を果たしていることが 示惨された。

察引用語 1. Vasuclar Endothelial Growth Factor (VEGF)

\section{P 108 急性炎症におけるHGFactivator这伝子発現の变化

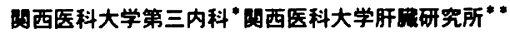 \\ 東京工業大学生命理工学部"**

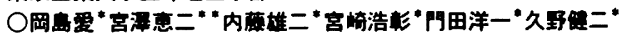

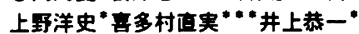

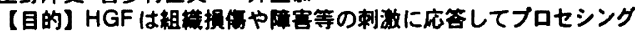
され、一本镍の不活性型 HGF から二本制の活性型 HGF に变埃さ れる。 HGFactivat or (HGFA) はセリンブロテアーゼでありHGF の活性化を制御するキーエンザイムである。前回、私逼はラット

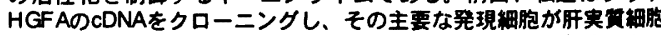

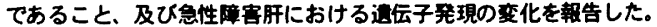
今回は、更にHGFAの病憼生理学的意艘を明らかにするため、急性 炎症におけるHGFAの迹伝子発現の变化を梌时し、併せて圆部害及 ひin vitr Oにおける变化も比較検討した。【方法】(1)急性炎症モテ ルは、Wistar 系雄性ラットにテレピン油 $(0.5 \mathrm{ml} / 100 \mathrm{~g} \mathrm{BW})$ を投 与し、畧障害モテルは

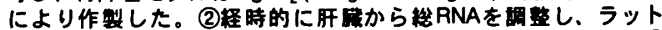
HGFA CDNAをプローフとしてノザンプロッティングを行った。(3)

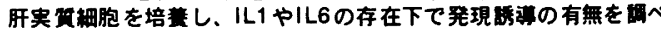
た。(4)急性期蛋白留として同定されているラットT- kininogen CDNAをプローフとしてフィルターをリハイブリした.【結果】(1) HGFA mRNAは急性炎症 12 時间後に無処而ラットに比へて䄪 2.5 倍 に墙加した。一方、T-kininogen mRNAは24時间後に発現が最大 となり、增加の程度は異なっていた。(2HGFA mRNA は图障害12

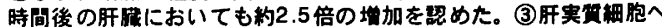
のIL1あるいは IL6の添加では、HGFA mRNA の㙩加は眼められな かった。【結論】(1)急性炎症時にHGFA这伝子の発現か撛道され、 このプロテアーゼかいわゆる急性期蛋白窗であることか呩唆された。 (2) $\mathrm{HgCl}_{2}$ 菆障害においては、何らかのメディエターが成与し、肝 紏胞のHGFA道伝子の発現を誘道していると考えられた。(3しかし

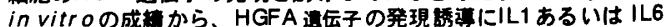
などの炎症性サイトカインの直接的な間与は否定的であった。 索引用語 1.HGFactivator 2.HGF 


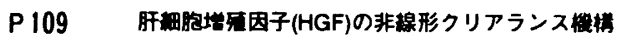

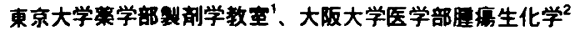

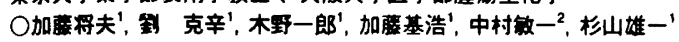
【目的】肝綢胞塔要因子(HGF)は肝賥胞に対する最も強力なmitogen である。HGFの生体内での俔きを解明する上で、その血中レベルの調

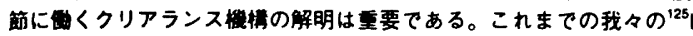
標偝HGFを用いた解析から、肝細胞表面のHGF受容体ならびにへバリ ン様物貝を介すると思われる低親和性取り込み機掅が重要であること が示战されている。今回、HGFの投与量を種々变化させることによっ て体内的婜の非湶形性を解析し、このようなメカニズムがどのように HGFの体内㡖を支眍しているかについて明かにすることを試みた。

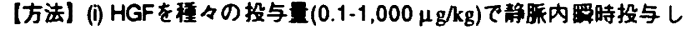
血慗中狠度推移をEIA法により湖定した。(ii) 種々の投与速度

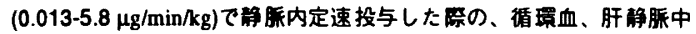

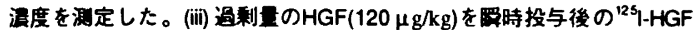
の肝取り込みクリアランス(CL $)$ の時間推移を評洒した。

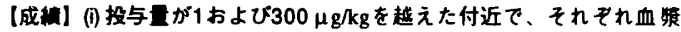
クリアランス(CL/mama) の飽和が筧察された。ヘバリンとの同時投与を 行ったところ、120 $\mu \mathrm{g} / \mathrm{kg}$ の HFF投与量ではほほ完全にCL $\mathrm{CL}_{\text {pama }}$ の低下 が梘察された一方、煌形領域である $0.3 \mu \mathrm{g} / \mathrm{kg}$ では完全ではなかった。

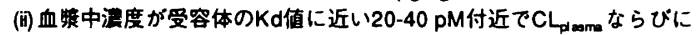
クリアランス腹器である肝での抽出率が低下した。(iii) 過剩のHGF投 与後、細胞表面へパリン様物質への結合を反映すると思われる heparin-washableなCLhに変化がないー方、受容体を介する取り込み を合むheparin-resistantな $\mathrm{CL}_{n}$ は有意な娍少の後に回復した。

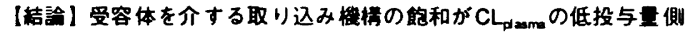

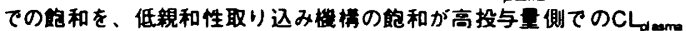
の解和を引き起こすことが示喽された。ヘバリンとの同時投与によっ て後者のメカニズムがより選択的に阻害されることが示喽された。 真引用語 1 . 肝細胞增死因子 2 . ヘパリン

P 110 Tissue factor pathway inhibitor (TF P I) による䀒

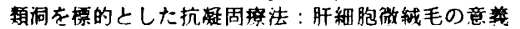

'埼玉医科大学第三内科, ${ }^{2}$ 東京大学第一内科

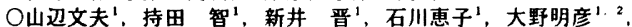

新井雅㭲 ${ }^{2}$, 松井 淳'

【目的】クッパー紐胞が活性化し tissue factor ( T F ) 活性が增加

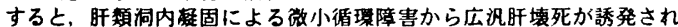
ろ。我々は，䀒移植後早期に出現する肝不全もこの機序に起因し，抗 政固察法により䀒障害が改善することを証明した。しかし，従来の抗

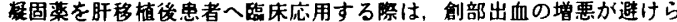
れない。今回，TFによる血液疑固の誘発を直接抑制する T F P I の 効果をラットで検討したところ，類洞内皮細胞か破壊された病㮩䀒て も䀒類洞を標的とした抗疑固法が可能であり，出血傾向を来さない ことを見いだしたので報告する。【方法と成緹】(1) Northern blotting 及ひ免度組織学的検討によると, 䀒類洞内皮細胞は他碏器の内皮 細胞と異なり、T F P I 発現か認められなかった。(2)組替え型 T F P Iをラットに静注すると，5分後には血中より消失し，盰に集糟した。 ヘパリンを追加静注すると T F P I は再び血中に回収された。 (3)T F P I 静注 5 分後の肝を兔度組織染色すると, 肝類洞に沿って著明な F P I 染色性が光影缽察された。へパリンを追加静注した䀒ではこの 染色性は消失した。(4)兔度電影に上万银察では，投与したT F P I の

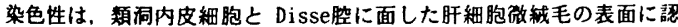
められた。(5UW波に24 時間以上冷保存した䀒では, 類洞内皮細胞 の破填像か電影稫察された。これら䀒では経門脈的に投与した T F P I は旰細胞微械毛膜に結合し，免度組織学的には旰類洞壁に沿った染 色性が認められた。6 6クッパー紐胞のT F 活性が著增している䀒部分 切除後エンドトキシンン誘発ラット肝不全モテルでは，TＦＰＩの静注 により肝障害が改善した。【考案】TF P I は流血中ではなく類洞内 皮細胞や肝細胞表面のヘパリノイドに結合して類洞内磁固を抑制した。 また，類洞内皮細胞か破霓された冷保存䀒においても，䀒細胞微䋐毛 に結合して肝類洞の抗烶固活性を発揮することが判明した。【結語】 T F P I は全身の出血傾向を誘発せず，また類洞内皮細胞か破壊され た場合でも䀒細胞表面をその代用として抗凝固活性を発揮する。旰移 植後患者における類洞内疑固の治有用となる可能性がある。 索引用語
P 111 肝切除における長時间血行遮断に伴う肝阻血度害とin situ coolingの奻果

大分医科大学第 1 外科

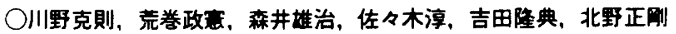
【目的】䠦床肝切除において施行される長時間連続全肝阻血 (Pringle 法)は，出血制限に有奻である反面，同時に阻血に伴う肝 障害も意起する. 今回, 肝阻血の影雷と併せてin situ coolingによ る肝冷却の効果を、原発性肝細胞盖(HCC)に対する肝切除例にお いて検討した.【対象/方法】1989年7月から1996年2月に当科に おいてHCCに対して施行された肝切除139症例を、1 群: 30 分间末 满の阻血 (50例)， 2 群: $30 \sim 50$ 分间の連続阻血 (26 例)、2C群: 肝冷 却併施(9例)，群:50分以上の連繶阻血 (30例)，3C群: 肝冷却併施 (24例)の5群に分け，術中出血吾，街後血洨生化学梌查について検 討した. 肝冷却は, 血行遮断に先立 $54^{\circ}$ C跳䣬化リンゲル500 mlの 門胉内注入により行った。 また政中，切除前と血流再開後60分に 肝生検を行った82例においてエラスターゼ染色を行い，再潅流後 肝障害の発生に関与する報告されている好中球漫网の程度 (counV10HPF)を評価した。【結果】(1術中出血量は1,2,3群各々 $1126,617,1029 \mathrm{ml} 2$ 群において有意な出血量の減少がみられた $(p<0.05)$. (2)術後GOT值の評価では50分以上の血行遮断群で強い 肝相胞障害を示した $(p<0.05)$. (3)肝組㳦内好中球漫洞(血流再開後 60 分/手術開始時)は1，2３群各々2.0，2.3，2.6 と阻血時間に比例し て增加した. (4)肝冷却により出血目は低下し(2C群: $403 \mathrm{ml}, 3 \mathrm{C}$ 群: $929 \mathrm{ml}$ )，好中球浸间も非冷却群に比し有意に㧕制された。【結 詥】肝流入血遮断により術中出血田は低下した。しかしなからら転 移性肝落と異なり，恔性肝疾急を高類度に合併するHCCに対する 肝切除においては，50分间以上の血流遮断は肝障害を有意に墥嗑 することが示され，長時间血流遮断が必要な症例において肝冷却 の併用は阻血陣害轻娍の手段として有奻なことが示喛された。

1. 肝切除 2. 肝阻血障害

P112阻血再灌流肝における肝障害機序：好中球漫洞と cytokine induced neutrophil chemoattractant $の$ 誘遄

東京慈恵会医科大学内科学第一講座

○深田弘幸，奥秋靖，称奶厚史，都野晋一，大川康彦，新智文，坂 口正已，高满宏樹，淁辺文時，相沢良夫，鐵谷幹男，戸田刚太郎 目的にれまで我々は、訮阻血再灌流により好中球漫閏を伴う肝障害が

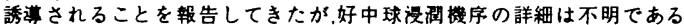
cytokine induced neutrophil chemoattractant (CINC) は，好中球の走 化作用を有するIL8 superfamilyに属するラットサイトカイである、そこで,ラトト

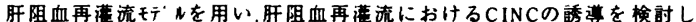

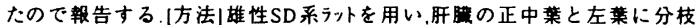

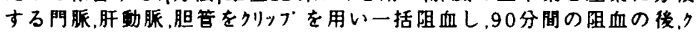

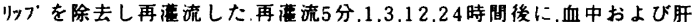
組織中CINCをIBL社揫CINCELISA キ外を用い测定し,CINC mRNAの肝

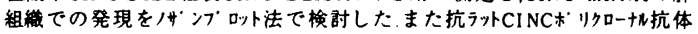
を一次抗体とするABC法を用い，肝組機CINCの免疫組䋨学的検索を行っ た对照として、シ十ム手術を施行したラットを用いだ成䋐血中CINCは、シャム 手術群では検出されなかったのに対し、再灌流5分後、1 3,12,24時間後

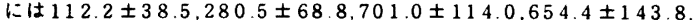
$108.5 \pm 40.7 \mathrm{pg} / \mathrm{m}$ に有意に高值を示した $(\mathrm{P}, 0.01)$. 秆組織中のCINCは， 再灌流5分後、1，3，12，24時間後で肝湿重量1 g 当たり $3349.2 \pm 1268.1$ $1372.4 \pm 717.9,2002.7 \pm 703.7,2907.4 \pm 623.5,1307.1 \pm 413.8$

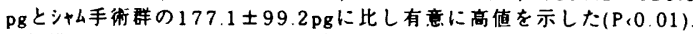
肝組繏中でのCINC mRNAの発現は、シ十手術群の発現强度を1とする と.再灌流 5 分後, 1.3 時間後では7.8，39.3，55.6 と経時的に湔增し、12 時 間後に最高の80.9となり.24時間後には30へと低下した.质疫組繶学的

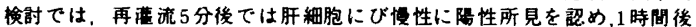
には科胞での淂性所見は娍少し.3時間後では類洞壁に沿ってび性

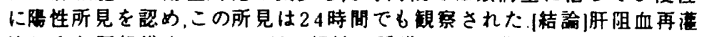
流により肝組瀻中にCINCが二相性に誘望され、再灌流初期には肝細胞 が、再灌流3時間以降は類洞壁細胞が、その産生細胞として示唆された。 㛟索用唔 1.阻血再灌流肝障害 2.cytokine induced neutrophil chemoattractant 
P 113 肝虚血・再潅流時の肝および血中過酸化脂質動態とその 測定意㧴 一末梢血を用いた肝虚血・再海流侮害のリアルタイム表示、 東北大学第一外科

○八巻孝之、鈴木正德、福原蜸治、海野倫明、成島陽一、坂本宣英、 簿田雅央、竹内丙午、内山哲之、㭢井直樹、松野正紀

【目的】肝虚血・再海流倁害には紐胞膜不飽和脂肪酸の脂啠過酸化が 関与するが、末梢血レベルての過酸化脂質動態とその測定意義につい ての詳細は明らかではない。われわれは、主要朕楼成脂質の過酸化物 であるPhosphatidylcholine hydroperoxide(PCOOH)をCL-HPLC法から定量 し、虚血再潅流時の肝における膜りン脂質過酸化反応の元進を、リア ルタイムに末梢血レベルで把握できるか否かを実験的に検討した。方 法】体重40KgのSPF豚24頭を用いた。虚血10,20,30分の3群とし、 Pringle氏法で肝流入血行遮断を行い、再海流直前, 10,20,30,60分後の肝 組織,肝静眽および末梢血PCOOH, 肝GSH,肝EnergyCharge(EC),AKBR, 血 墏GOT, GPT,LDHを测定した。肝の租織学的変化はHE染色を中心とし て組瀻標本を作製し、光顯的に検討した。【結果】肝PCOOHは3群と 6 再海流後経時的に增加し、虚血30分、再海流60分後で1903.7士

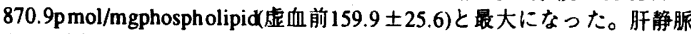
および末梢血PCOOHは肝と同様、経時的に增加し、虚血 30 分・再海

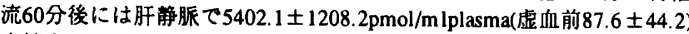

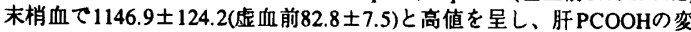
動と極めて強い相関を示した。肝ECおよびAKBRは再潅流直前に有意 に低下したが、3群とも再潅流後60分にはほほ前値に復し、また、肝 GSHは経時的な娍少を示し、虚血30分再潅流 60分後に最低となった。 虚血30分後の光顕像ではZone Iを中心に篗血や肝細胞索の乱れが観察 され、再潅流60分後ては細胞の腫大や空胞化、染色性の低下、核浱綟 が認められた。【結語】虚血・再潅流時の肝障害は、再潅流早期に肝 から血中へ逸脱したPCOOHの経時的測定から把暒できた。肝の脂質 過酸化六進および肝エネルギー代謝跡害を末梢血レベルで鋔敏かつリ アルタイムに把握する簡便なモニタリングシステムを確站する今回の 試みは、臨床上、肝不全発生を予知する有力な手段となりうる。 $\begin{array}{lll}\text { 索引用語 } & \text { 1. 虚血・再海流障害 } \quad 2 . \mathrm{PCOOH}\end{array}$

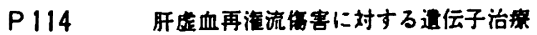

(九州大学第 1 病理"、同第 2 外科 ${ }^{2} 、$ 大阪大学細胞生体工学

$$
\text { センター゙) }
$$

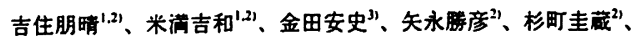
居石克夫"

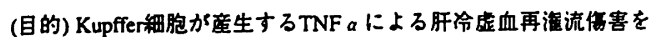

特異的に抑制する目的でTNF $\alpha$ antisense oligonucleotide (ODN) を膜 䜿合リポソーム (HVJ-L)を用いて移植肝へ蔀入するという迹伝子 治療の功物実駼を周始した。(方法)ラット摘出肝の冷保存中にTNF $\alpha に$ 对する antisense ODN (18mer) を含むHVJ-L (TNF-AS 群)、 Balanced Salt Saline (BSS) を含むHVJ-L (Vector群) あるいはBSS ( ントロール群)を释門脈的に投与し、6時問保存後䏕移植した。再 潅流4時間後の血消GPT、LDH、肝組織 (各n=3) 及ひ 1 週間生存率 (各 $n=2,3,4)$ を比较した。(結果)GPT (IU/L) はTNF-AS群、Vector群、

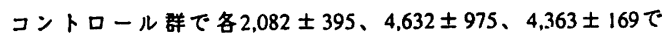
TNF-AS群と他の2群間に有意差を認めた $(p<0.05 、 p<0.01)$ LDH (IU/L) は各24,352 $\pm 6,439 、 43,110 \pm 10,415 、 45,831 \pm 18,176$ で

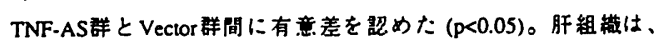
TNF-AS群は他の 2 群に比し、類洞内人の好中球の漫网が少ない頋 向にあった。1䢙間生存事は各2/2,0/3,1/4であった。(考察)膜辟 合リポソームを用いたTNF $a$ antisense ODNの透伝子望入により、 肝虚血再潅流伤害が改善された。

索引用語 1.HVJ・リポソーム 2.TNF-a

\section{P 115 遗伝子道入による肝虚血再濩流陴害の制彻}

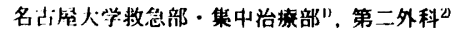

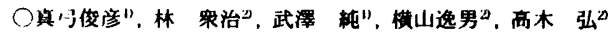
[月的]われわれはこれまで SOD 等の種々の遭伝子導入を試み、

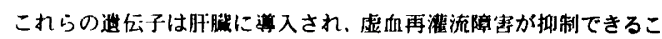
とを報斵してきた。そこで今回は術前に cytoprotective な I-10

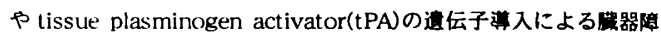
䆵の制御について検討した。

[刘䒺および方法] IL-10, tPA を組み込んだアテノウィルスベクタ 一を作誠した(対照 : Adex/ LacZ)。Wister Ratにモデル作成4 日 前に $1 \times 10^{4}-1 \times 10^{1 " 1} \mathrm{CFU} / \mathrm{ml}$ のベクターを注入し, $\mathbb{I}-10(\mathrm{n}=9)$, $\mathrm{tPA}(\mathrm{n}=10)$ または両者(IL-10+tPA, $\mathrm{n}=12)$ を導入し，対照 $(\mathrm{n}=10)$ と 比較した。1 時間の肝左菓クランブによる虚血後, 再灌流した。再 隻流後 1 および 24 時問後にTNF $\alpha$, GOT, GPT, LDHを测定した。 [結果] 対照群に比較し，障害は IL-10、tPAの算入により減少す る倾|们があり、IL-10+tPA によって有意に減少し(24h 後: GOT: $1828 \mathrm{Il}$ / / vs 4700 in control, GPT: $1329 \mathrm{IU} / \mathrm{l}$ vs 3347 in control, LDH: 1172IL// vs 7297 in control), TNF $\alpha$ も有意に低下した (20.8pg/ml vs 55.8 in control)。

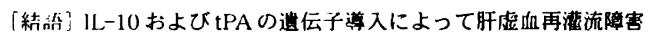
を制御できる可能性が示唆された。

索引用湻 1. 肝虚血再灌流 2. 造伝子

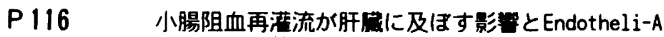
receptor antagonist の効果について

島根医科大学第 2 外科

O祖田由起子、山野井赣、槙野好成、Osama Nazmy El-Assal、

大森治澍、河野仁志、永末直文

腸管埭死や阻血再雚流後には軽度から中等度の肝噇害を認めるこ

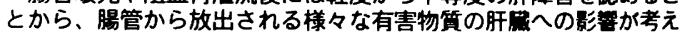
られてきた。われわれは先の実験から阻血腸管で産出された

Endothelin-1 (ET-1)か、、門脈血中にも高湌度で放出されることをつ かみ、腸管からのET-1放出が肝血流にも影㛭を及ぼすのではないか と推察した。今回われわれは、ET A receptor antagonistのB0485

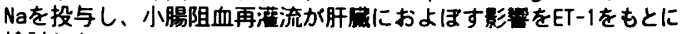
検討した。

雄性SDラット $(250 \sim 340 \mathrm{~g})$ に3 日間メトロニタール30mgを経口 投与後、60分の小腸温阻血後再满流した。BQ485Na 治療群 (阻血、 再萑流前 15 分にそれそれ7.5 m $/ \mathrm{kg}$ を静脈内投与) と、無治痖群（生 理食塩水 $1 \mathrm{ml} / \mathrm{kg} / \mathrm{min}$ ) とに分けて血压、小腸局所の血流是およひ肝 血流量、血中訮䤃紊量、術後生存率を钼察した。

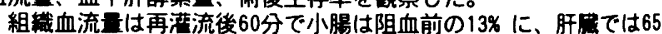
\%にまで低下した。B0485 Na 投与は血圧には有意な影㫼を与えず に、小腸血流量は65\%、肝缄では78\% とともにコントロール群に比べ 有意に良好に保持された。血中肝醉基量はAST が再灌流後了時間で 48. 5IU/Lから208.4IU/L と上昇したが、BQ485Na 投与群では91.3IU /ににととまった（p 值0.003）。ALTは術前時17.0IU/Lに对し、無治 㞠群37.5IU/L、BQ485Na投与群29.8IU/Lで有意差を認めなかった。70 分阻血術後の7 日間生存率は無治湶群20\% (2/10)、治療群80\%(8/10) であった。

小腸阻血再满流後に小腸で産生されたET-1は肝到達して肝血 流滅少、肝障害を引き起こした。ET A reseptor antagonistの投与 は全身血圧に影䈏を与えることなく、局所の小渴のみならず肝血流

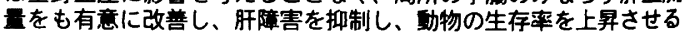
ことが明らかとなった。

索引用語 1. Endothel in-1(ET-1) 2. BQ485Na(ET A receptor antagonist) 